J. Dairy Sci. 100:2415-2415

https://doi.org/10.3168/jds.2017-100-3-2415

(c) American Dairy Science Association ${ }^{\circledR}, 2017$.

\title{
Corrigendum to "Linear and nonlinear genetic relationships between type traits and productive life in US dairy goats" (J. Dairy Sci. 100:1232-1245)
}

\author{
V. J. Castañeda-Bustos, H. H. Montaldo, M. Valencia-Posadas, L. Shepard, S. Pérez-Elizalde, \\ O. Hernández-Mendo, and G. Torres-Hernández
}

On page 1233 (second paragraph), the third sentence should read "Their study considered that the genetic trend for productive life at 72 mo could increase up to $38.3 \%$ per generation (with respect to direct selection) when one of these traits studied was used as a selection criterion."

On page 1237, in Table 2, the unit for teat diameter should be (score), and footnote 6 should read " ${ }^{6}$ Ratio of herd-sire effect (HS) = HS variance/total variance."

On page 1239, in Table 4, footnote 1 should read "1 Difference in the adjusted coefficient of determination $\left(\mathrm{R}^{2}\right.$ adj) between second degree and first degree regression models of breeding values."

The authors regret the errors.

\section{REFERENCES}

Castañeda-Bustos, V. J., H. H. Montaldo, M. Valencia-Posadas, L. Shepard, S. Pérez-Elizalde, O. Hernández-Mendo, and G. Torres-Hernández. 2017. Linear and nonlinear genetic relationships between type traits and productive life in US dairy goats. J. Dairy Sci. 100(1):1232-1245. https://doi.org/10.3168/jds.2016-11313. 